\title{
THE PRE-MERGER EFFICIENCY OF BANKS: EVIDENCE IN INDONESIA STATE-OWNED ISLAMIC BANKS
}

\author{
Atika Ayuning Tyas ${ }^{a}$ \\ Aam Slamet Rusydianab \\ ${ }^{a}$ Sharia Economics Department, Faculty of Economics and Management, IPB University \\ ${ }^{\mathrm{b}}$ Sharia Economic Applied Research and Training (SMART) Consulting Indonesia \\ Email: atikatyas23@gmail.com ${ }^{a}$; aamsmart@gmail.com ${ }^{b}$
}

ARTICLE HISTORY

Received:

19 November 2020

Revised:

7 December 2020

Accepted:

15 December 2020

Online available:

30 June 2021

Keywords:

State-Owned Islamic

Bank,

DEA,

Efficiency,

Merger.

*Correspondence:

Name:

AtikaAyuningTyas

Email:

atikatyas23@gmail.com

\section{ABSTRACT}

In an effort to improve the development of the sharia economy in Indonesia, the Ministry of State-Owned Enterprises (BUMN) has decided to carry out a merger of BRI Syariah, Bank Syariah Mandiri, and BNI Syariah becomes Bank Syariah Indonesia. This merger plan is implemented to increase the share of the Islamic banking market so that it can compete with conventional banking. In order to be able to compete with conventional banking, Islamic banks must be able to have efficient performance and high productivity. This research is a quantitative study to analyze and compare the performance efficiency of BRISyariah, Bank Syariah Mandiri, and BNISyariah with the performance efficiency of ten conventional banks for the 20162019 periods using the Data Envelopment Analysis (DEA) method with five analysis models to obtain various considerations in preparing the merger plan. The estimation results show that if the three Islamic banks are merged, they will have inefficient performance with an efficiency score of 0.86 . On the other hand, if only two Islamic banks are merged, namely BNISyariah and BRISyariah, it will produce perfect efficiency values.

\section{INTRODUCTION}

The development of the world's first Islamic bank began when the Mit Ghamr Bank was established in Egypt in the 1960s (Havidz \& Setiawan, 2015). Initially, the establishment of a sharia bank was intended to meet the needs of the Muslim population in a country with a majority Muslim population (Mokhtar et al., 2006). However, in its development, many countries have established Islamic banks to meet the demand of the population for Islamic financial products such as Islamic financing (Kablan \& Yousfi, 2013).

Islamic banks develop not only in countries with a majority Muslim population, but Islamic banks are also able to develop in countries with non-Muslim majority populations such as Britain and America (Irfan et al., 2014). Even Islamic banks have the 
highest growth rates in various countries in the world, especially in the Middle East and Southeast Asian countries, including Indonesia (Rahman, 2013).

In Indonesia, the pioneer of the establishment of an Islamic bank is Bank Muamalat Indonesia which was founded in 1991 (Suryani, 2012). Over time, based on the Sharia Banking Statistics data published by the Financial Services Authority (OJK) in 2019 , it shows that the number of Islamic banking has reached 14 Islamic Commercial Banks, 20 Sharia Business Units, and 164 Sharia Rural Banks. Meanwhile, according to the 2018 Global Islamic Finance Report, the Islamic finance industry in Indonesia was ranked sixth after Malaysia, Iran, Saudi Arabia, UAE, and Kuwait. The index value of Indonesia's Islamic finance industry in 2018 was 24.13 on a scale of 100 and was ranked sixth in the world (Cambridge Institute of Islamic Finance, 2018). The development of Islamic banking in Indonesia has received support from the government through Law Number 21 concerning Islamic Banking.

As an effort to increase the growth of Islamic banks in Indonesia, the government has issued various regulations such as the enactment of a spin-off policy and one that has just been drafted, namely the merger of three state-owned Islamic banks. The three Islamic banks are Bank BRI Syariah, Bank BNI Syariah and Bank Mandiri Syariah. The plan for the merger was ratified with the signing of the Condition Merger Agreement (CMA) of the three Islamic banks which was carried out on October 12, 2020. The plan for this merger will be implemented no later than 2021.

The merger between the three largest Islamic banks in Indonesia, namely BRI Syariah, BNI Syariah, and Bank Mandiri Syariah, will succeed if these Islamic banks could maintain efficient performance and high productivity. Therefore, this study will analyze the comparison of the performance efficiency of the three Islamic banks that will be merged with the performance of ten conventional banks using five analysis models for the 2016-2019 period. There has been no similar research, where this study analyzes the effect of the merger of BRI Syariah Bank, BNI Syariah Bank, and Mandiri Syariah Bank on the efficiency level of the bank's performance, especially before the merger. The results of the analysis of this study are expected to be the best consideration for Bank Indonesia (BI) and the Financial Services Authority (OJK) as regulators in the process of making decisions on the merger plan. This study also expected to see the performance of each of these Islamic banks.

\section{LITERATURE REVIEW}

Efficiency is defined as a measure of effectiveness without wasting time, effort, and with minimum skills. The term efficiency is different from effectiveness; both are used to describe the performance of an entity. However, efficiency is focused on using 
minimum inputs to produce optimum output (Jaouadi \& Zorgui, 2014). Efficiency theory is closely related to consumption theory and production theory in microeconomics. The meaning of efficiency in production theory is a state of the company when it is able to generate maximum profit in its production activities and can be in the form of a measuring instrument that functions as an appraiser of producer choices. In consumption theory, efficiency occurs when consumers are able to maximize their satisfaction and utility. Efficiency will be optimal if the company can maximize output by using fixed inputs or by minimizing the use of inputs to achieve the same level of output (Karim, 2018).

According to Farrell (1957), company efficiency consists of two components, namely technical efficiency and allocative efficiency. Technical efficiency is a relationship in the use of inputs to produce outputs on best practices in the Decision-Making Unit (DMU). Allocative efficiency is the company's ability to use input in optimal proportions. The combination of technical efficiency and allocative efficiency will result in economic efficiency.

In measuring efficiency performance, it can be done with two approaches, namely the parametric and non-parametric approaches. The parametric approach is a measure of efficiency in which the model specifies certain requirements about the population parameters that are the object of the research. In contrast, the nonparametric approach is a measurement whose model does not specify the parameters of the population that is the parent of the research sample (Hidayah \& Purnomo, 2016). Analysis using a parametric approach can be calculated using three methods, namely the Stochastic Frontier Approach (SFA), Distribution Free Approach (DFA), and Thick Frontier Approach (TFA) (Berger \& Humphrey, 1997). If you use a non-parametric approach, you can use the Data Envelopment Analysis (DEA) and Free Disposable Hull (FDH) methods.

Data Envelopment Analysis (DEA) was first introduced by Charnes, Cooper, and Rhodes in 1978. This method is a mathematical linear programming technique used to evaluate the efficiency performance of a decision-making unit (DMU). In conducting the analysis, the DEA method accommodates input and output variables to produce a single efficiency value which is used to measure technical efficiency, pure technical efficiency, and efficiency scale.

The analysis of this study uses a non-parametric approach, which is DEA, in measuring the efficiency of Islamic banks and conventional banks. According to Insukindro et al. (2000), there are three benefits obtained from using DEA in measuring efficiency, namely as a benchmark for obtaining relative efficiency, which is useful for facilitating comparisons between the same economic units, measuring various variations in efficiency between economic units to identify the causative factorsand determine policy implications so as to increase the level of efficiency. 
In general, the DEA method has two frequently used models, namely the Charnes, Cooper, and Rhodes (CCR) and Baker, Charnes, and Cooper (BCC) models(Cooper et al., 2004). The CCR model was first introduced by Charnes, Cooper, and Rhodes in 1978. This model assumes a constant return to scale (CRS), which indicates that the addition of production factors (input) will not have an impact on additional production (output). In addition, the CRS model also assumes that firms have the same internal and external conditions and operate in perfectly competitive markets. The CRS condition indicates that the Islamic life insurance company operates at the most productive scale size and technically and purely technically efficient (Cooper et al., 2006). However, the CRS model is only suitable for conditions in which the DMU operates optimally.

The BCC model is one of the DEA method models first introduced by Baker, Charner, and Cooper in 1984. This method assumes a variable return to scale (VRS), indicatingthat the increase in input and output does not have the same proportion. Increasing the proportion can either increase return to scale (IRS) or decrease return to scale (DRS). Sharia life insurance companies are assumed to use the BCC model not to have the same internal and external conditions and do not operate in a perfectly competitive market.

Several researches that have carried out applications for measuring efficiency in the Islamic banking industry in Indonesia can be found in research byHafez and Halim (2019); Rusydiana et al. (2019); Rusydiana and Marlina (2019). Rusydiana and Sanrego (2018) have also conducted an analysis related to the framework for measuring the performance of Islamic banks in relation to the concept of efficiency. The first is the maslahah Efficiency. This framework combines measurements from the side of efficiency with the perspective of maqasid sharia(Rusydiana \& Firmansyah, 2017). The second is a framework for measuring the efficiency and stability of Islamic banks in one framework (Rusydiana, 2018b). Finally, the measurement of the level of productivity of Islamic banks in terms of changes in the level of efficiency (EFFCH) and the level of change in the use of technology or technological change (TECH) which has an impact on productivity (Rusydiana, 2018a).

Based on the results of the analysis by Rusydiana and Marlina (2019), when viewed from the category of financial efficiency and social efficiency levels, Islamic banks that have high financial efficiency and social efficiency values consist of Bank Syariah Mandiri and BNI Syariah. Meanwhile, BRI Syariah is included in thequadrant with a low level of efficiency yet relatively high social efficiency. Meanwhile, according to Rusydiana andSanrego (2018), when viewed from the maslahahefficiency concept, Bank Syariah Mandiri is included in quadrant 2 with an average efficiency value of $65 \%$ and MSI 
0.202.On the other hand, BRI Syariah is included in quadrant 3 with an average efficiency value of $65 \%$ and MSI 0.208 , while BNI Syariah is included in quadrant 4 with an average efficiency value of $47 \%$ with MSI 0.172 .

A study that is relatively relevant to this research related to measuring the efficiency of state-owned Islamic banks with cases abroad is that conducted by Shawtari et al. (2014). Using the Data Envelopment Windows Analysis (DEWA) approach, Shawtari et al. (2014) tried to analyze the efficiency of the banking industry in Yemen for the period 1996 to 2011. The findings indicate that the banking industry in Yemen generally experienced a downward trend and instability inefficiency during the study period. The study also found that the majority of Shawtari et al. (2014)conventional banks are relatively more stable although inefficient. Meanwhile, Islamic banks and foreign banks have become more efficient over time, state-owned banks and private banks are relatively lagging behind in terms of achieving levels of efficiency.

Meanwhile, research on the efficiency of Islamic banks compared to conventional banks was carried out, for example, by Hassan (2006), who describes the cost, profit, revenue, and X-efficiency of Islamic banks around the world. First, this study makes a stochastic cost frontier approach to calculate the cost efficiency of Islamic banks in the 1996-2002 period. Second, calculating profit efficiency by considering cost and revenue. Third, determine revenue efficiency to determine whether Islamic banks make banking product innovations to increase their income.Fourth, using non-parametric Data Envelopment Analysis (DEA) methods to calculate overall efficiency, namely technical, pure technical, allocative, and scale efficiency. The result is that, on average, the Islamic banking industry is relatively less efficient than conventional banks.

Currently, there is relatively no research related to the effect of the merger of Bank BRI Syariah, Bank BNI Syariah, and Bank Mandiri Syariah on the level of efficiency of the bank's performance, especially before the merger. Based on the formulation of the problem, the hypothesis in this study is that there is no effect of the merger on differences in the level of efficiency of Islamic banks before and after the merger.

\section{RESEARCH METHODS}

The population used in this study are three state-owned sharia banks that will be merged, namely Bank BRI Syariah, Bank BNI Syariah, and Bank Syariah Mandiri, with ten conventional banks for the period 2016-2019. This research is a quantitative study using secondary data obtained from annual financial reports.

This study uses the Data Envelopment Analysis (DEA) method with the output orientation BCC model. Analysis using the DEA method results in a company efficiency value in the range 0-1 (Sabiti et al., 2017). A bank company will be considered efficient if it has an efficiency value close to a value of 1 and is said to be inefficient if it approaches 
a value of 0 . In this study, the variables used to analyze performance efficiency are input variables consisting of deposits, general and administrative expenses, and personnel expenses. While the output variables used are financing and income. In this study, the measurement of bank performance efficiency was carried out using five models to obtain various considerations for the merger plan of state-ownedlslamic banks. The five models are:

1. comparison of the performance efficiency of each of the three Islamic banks with the efficiency of the performance of ten conventional banks;

2. comparison of the performance efficiency of state-owned sharia banks (merger of BRI Syariah, BNI Syariah, and Bank SyariahMandiri) with the performance efficiency of ten conventional banks;

3. comparison of the efficiency of the merger performance of two Islamic banks (BNISyariah and BRISyariah) compared to the performance efficiency of Bank Syariah Mandiri and ten conventional banks;

4. comparison of the efficiency of the merger performance of two Islamic banks (Bank Syariah Mandiri and BRISyariah) compared to the performance efficiency of BNISyariahand ten conventional banks;

5. comparison of the efficiency of the merger performance of two Islamic banks (BNISyariah and Bank Syariah Mandiri) compared to the efficiency of the performance of BRISyariah and ten conventional banks.

Several studies related to the measurement of performance efficiency using DEA, both theoretical and applicable, have been carried out. These studies have been conducted by Benarda et al. (2016); Khan and Noreen (2014); Miniaoui and Chaibi (2014); Rahman (2013); Sabiti et al. (2017); Shahreki et al. (2012); Tuffahati et al. (2016). The analysis tool in this research is Max DEA. The method presents in this study to measure the level of performance efficiency of three Islamic banks and ten conventional banks in Indonesia for the period 2016-2019.

\section{RESULT AND ANALYSIS \\ Definition of Operational Variables}

This chapter will explain the general description of the input and output variables of operational activities of three Islamic banks and 10 conventional banks used in estimating efficiency scores. The input variables used include deposits, general and administrative expenses and personal expenses, while the output variables used include financing and income. Table 1 shows that the average deposit value of three Islamic banks and 10 conventional banks for the 2016-2019 period in Indonesia reached 296.022.328 million rupiah with a minimum value of 1.676 .397 million rupiah and a maximum value of 1.039.166.488 million rupiah. Meanwhile, the standard deviation of 
deposits reached 331.856.725 million rupiah. The value of the standard deviation of the deposit variable indicates that there is a large difference in the value of each bank's deposits.

Table 1

Definition of OperationalVariables (in Million Rupiah)

\begin{tabular}{|c|c|c|c|c|}
\hline Variables & Average & $\begin{array}{l}\text { Standard } \\
\text { Deviation }\end{array}$ & Minimum & Maximum \\
\hline \multicolumn{5}{|l|}{ Input variables: } \\
\hline Deposits & $296,022,328$ & $331,856,725$ & $1,676,397$ & $1,039,166,488$ \\
\hline $\begin{array}{l}\text { General and Administrative } \\
\text { Expenses }\end{array}$ & $6,945,868$ & $15,607,048$ & 16,048 & $96,922,572$ \\
\hline Personal Expenses & $6,049,322$ & $6,955,397$ & 112,349 & $24,243,276$ \\
\hline \multicolumn{5}{|l|}{ Output variables: } \\
\hline Financing & $112,717,400$ & $136,669,190$ & $4,458,965$ & $539,862,076$ \\
\hline Income & $10,246,487$ & $13,410,039$ & 70,584 & $43,431,933$ \\
\hline
\end{tabular}

Source: Financial Report of Tree Islamic Bank and Ten Conventional Bank in Indonesia

\section{Model 1}

In this model, the three Islamic banks that will be merged are Bank Syariah Mandiri (BSM), BRI Syariah (BRIS), and BNI Syariah (BNIS), each of which will be compared to the efficiency score of 10 conventional banks. According to Table 2, it can be seen that in the 2016-2019 period BNISyariah had an average score of perfect efficiency and was ranked 2nd, while BRISyariah had an average efficiency score of 0.90 and was ranked eighth and BankSyariahMandiri had an average score efficiency of 0.59 by being ranked 12th. Based on these results, BankSyariahMandiri has the lowest efficiency score of the three banks that will be merged.

Table 2

The Value of the Efficiency Score Model-1

\begin{tabular}{|c|c|c|c|c|c|c|c|}
\hline No & DMU & 2016 & 2017 & 2018 & 2019 & Mean & Rank \\
\hline 1 & Mandiri & 0.63 & 0.85 & 1.00 & 1.00 & 0.87 & 9 \\
\hline 2 & $\mathrm{BCA}$ & 1.00 & 0.96 & 1.00 & 1.00 & 0.99 & 4 \\
\hline 3 & $\mathrm{BNI}$ & 0.96 & 0.96 & 1.00 & 1.00 & 0.98 & 6 \\
\hline 4 & BRI & 1.00 & 0.98 & 1.00 & 1.00 & 0.99 & 3 \\
\hline 5 & BTN & 1.00 & 1.00 & 1.00 & 1.00 & 1.00 & 1 \\
\hline 6 & Bumi Arta & 0.88 & 1.00 & 1.00 & 1.00 & 0.97 & 7 \\
\hline 7 & CIMB & 0.82 & 0.83 & 0.91 & 0.91 & 0.86 & 10 \\
\hline 8 & Danamon & 0.96 & 1.00 & 1.00 & 1.00 & 0.99 & 5 \\
\hline 9 & Mega & 0.44 & 0.47 & 0.62 & 0.71 & 0.56 & 13 \\
\hline 10 & Permata & 1.00 & 0.67 & 0.70 & 0.72 & 0.77 & 11 \\
\hline 11 & BNIS & 1.00 & 1.00 & 1.00 & 1.00 & 1.00 & 2 \\
\hline 12 & BRIS & 1.00 & 0.74 & 1.00 & 0.88 & 0.90 & 8 \\
\hline 13 & BSM & 0.57 & 0.57 & 0.59 & 0.64 & 0.59 & 12 \\
\hline
\end{tabular}

Source: DEA Output (Data Processed)

\section{Model 2}

Analysis in the second model combines the three Islamic banks into a stateowned sharia bank to calculate the efficiency value. The efficiency score of the state- 
owned Islamic bank will then be compared with the efficiency score of ten other conventional banks. Based on Table 3, it can be seen that when the three Islamic banks were merged, the state-owned Islamic bank had an efficiency score of 0.86 and was ranked ninth. This score is lower than the efficiency score of its conventional system banks, namely BRI is in third place, BNI is in fifth place, and Bank Mandiri is in seventh place.

Table 3

Value of the Efficiency Score Model-2

\begin{tabular}{clcccccc}
\hline No & \multicolumn{1}{c}{ DMU } & $\mathbf{2 0 1 6}$ & $\mathbf{2 0 1 7}$ & $\mathbf{2 0 1 8}$ & $\mathbf{2 0 1 9}$ & Mean & Rank \\
\hline 1 & Mandiri & 0.63 & 0.85 & 1.00 & 1.00 & 0.87 & 7 \\
2 & BCA & 1.00 & 0.99 & 1.00 & 1.00 & 0.99 & 2 \\
3 & BNI & 0,96 & 0.96 & 1.00 & 1.00 & 0.98 & 5 \\
4 & BRI & 1.00 & 0.98 & 1.00 & 1.00 & 0.99 & 3 \\
5 & BTN & 1.00 & 1.00 & 1.00 & 1.00 & 1.00 & 1 \\
6 & Bumi Arta & 0.88 & 1.00 & 1.00 & 1.00 & 0.97 & 6 \\
7 & CIMB & 0.82 & 0.83 & 0.91 & 0.91 & 0.86 & 8 \\
8 & Danamon & 0.97 & 1.00 & 1.00 & 1.00 & 0.99 & 4 \\
9 & Mega & 0.44 & 0.47 & 0.62 & 0.71 & 0.56 & 11 \\
10 & Permata & 1.00 & 0.68 & 0.71 & 0.73 & 0.78 & 10 \\
11 & BNIS-BRIS-BSM & 0.90 & 0.83 & 0.86 & 0.86 & 0.86 & 9 \\
\hline
\end{tabular}

Source: DEA Output (Data Processed)

\section{Model 3}

Meanwhile, in the third model, the merger of two Islamic banks, namely BNI Syariah and BRI Syariah, is conducted to compare the efficiency scores of Bank Syariah Mandiriand ten other conventional banks. According to Table 4, it can be seen that if only BNI Syariah and BRI Syariah are merged, the efficiency score will reach a perfect score. The result means that if only the two Islamic banks are combined, it is possible that the two Islamic banks will have an efficient performance when the merger is carried out. However, Bank Syariah Mandirihas a relatively low average efficiency score of 0.58 and is ranked 11th out of 12 banks.

Table 4

The Value of the Efficiency Score Model-3

\begin{tabular}{cllccccc}
\hline No & DMU & $\mathbf{2 0 1 6}$ & $\mathbf{2 0 1 7}$ & $\mathbf{2 0 1 8}$ & $\mathbf{2 0 1 9}$ & Mean & Rank \\
\hline 1 & Mandiri & 0.63 & 0.85 & 1.00 & 1.00 & 0.87 & 8 \\
2 & BCA & 1.00 & 0.97 & 1.00 & 1.00 & 0.99 & 4 \\
3 & BNI & 0.96 & 0.96 & 1.00 & 1.00 & 0.98 & 5 \\
4 & BRI & 1.00 & 0.98 & 1.00 & 1.00 & 0.99 & 3 \\
5 & BTN & 1.00 & 1.00 & 1.00 & 1.00 & 1.00 & 1 \\
6 & Bumi Arta & 0.88 & 1.00 & 1.00 & 1.00 & 0.97 & 7 \\
7 & CIMB & 0.82 & 0.83 & 0.91 & 0.91 & 0.86 & 9 \\
8 & Danamon & 0.96 & 1.00 & 1.00 & 0.93 & 0.97 & 6 \\
9 & Mega & 0.44 & 0.47 & 0.62 & 0.71 & 0.56 & 12 \\
10 & Permata & 1.00 & 0.66 & 0.69 & 0.72 & 0.76 & 10 \\
\hline
\end{tabular}




\begin{tabular}{cllllllc}
\hline 11 & BNIS-BRIS & 1.00 & 1.00 & 1.00 & 1.00 & 1.00 & 2 \\
12 & BSM & 0.55 & 0.56 & 0.59 & 0.63 & 0.58 & 11 \\
\hline \multicolumn{2}{l}{ Source: } & DEA Output (Data Processed)
\end{tabular}

\section{Model 4}

In the fourth model, the merger of two Islamic banks, namely Bank Syariah Mandiriand BRI Syariah, is conducted to compare the efficiency scores of BNI Syariah and ten other conventional banks. Based on Table 5, it can be seen that if only Bank Syariah Mandiriand BRISyariah were merged, the efficiency score would reach 0.70 and would rank 11th. This means that if only the two Islamic banks are combined, it is possible that the two Islamic banks will have inefficient performance because they have not been able to manage their inputs to produce optimal output. While BNISyariah has a perfect average performance efficiency score in the 2016-2019 period.

Table 5

The Value of the Efficiency Score Model-4

\begin{tabular}{cccccccc}
\hline No & DMU & $\mathbf{2 0 1 6}$ & $\mathbf{2 0 1 7}$ & $\mathbf{2 0 1 8}$ & $\mathbf{2 0 1 9}$ & Mean & Rank \\
\hline 1 & Mandiri & 0.63 & 0.85 & 1.00 & 1.00 & 0.87 & 8 \\
2 & BCA & 1.00 & 0.96 & 1.00 & 1.00 & 0.99 & 4 \\
3 & BNI & 0.96 & 0.96 & 1.00 & 1.00 & 0.98 & 6 \\
4 & BRI & 1.00 & 0.98 & 1.00 & 1.00 & 0.99 & 3 \\
5 & BTN & 1.00 & 1.00 & 1.00 & 1.00 & 1.00 & 1 \\
6 & Bumi Arta & 0.88 & 1.00 & 1.00 & 1.00 & 0.97 & 7 \\
7 & CIMB & 0.82 & 0.83 & 0.91 & 0.91 & 0.86 & 9 \\
8 & Danamon & 0.96 & 1.00 & 1.00 & 1.00 & 0.99 & 5 \\
9 & Mega & 0.44 & 0.47 & 0.62 & 0.71 & 0.56 & 12 \\
10 & Permata & 1.00 & 0.67 & 0.70 & 0.72 & 0.77 & 10 \\
11 & BSM-BRIS & 0.69 & 0.67 & 0.72 & 0.73 & 0.70 & 11 \\
12 & BNIS & 1.00 & 1.00 & 1.00 & 1.00 & 1.00 & 2 \\
\hline Source: DEA Output (Data Processed) & & & & &
\end{tabular}

Model 5

The analysis in the fifth model is carried out by combining two Islamic banks, namely BNISyariah and Bank Syariah Mandiri, to be compared with the efficiency score of BRISyariah and ten other conventional banks. Based on Table 6, it can be seen that if only BNISyariah and Bank Syariah Mandiriare merged, the efficiency score will reach 0.81 and rank tenth. This means that if only the two Islamic banks are combined, it is possible that the two Islamic banks will have inefficient performance in their operational activities and need to improve their performance efficiency by combining inputs to produce optimal output. Meanwhile, BRISyariah has a perfect average performance efficiency score in the 2016-2019 period. 
Table 6

The Value of the Efficiency Score Model-5

\begin{tabular}{cccccccc}
\hline No & DMU & $\mathbf{2 0 1 6}$ & $\mathbf{2 0 1 7}$ & $\mathbf{2 0 1 8}$ & $\mathbf{2 0 1 9}$ & Mean & Rank \\
\hline 1 & Mandiri & 0.63 & 0.85 & 1.00 & 1.00 & 0.87 & 8 \\
2 & BCA & 1.00 & 0.98 & 1.00 & 1.00 & 0.99 & 3 \\
3 & BNI & 0.96 & 0.96 & 1.00 & 1.00 & 0.98 & 6 \\
4 & BRI & 1.00 & 0.98 & 1.00 & 1.00 & 0.99 & 4 \\
5 & BTN & 1.00 & 1.00 & 1.00 & 1.00 & 1.00 & 1 \\
6 & Bumi Arta & 0.88 & 1.00 & 1.00 & 1.00 & 0.97 & 7 \\
7 & CIMB & 0.82 & 0.83 & 0.91 & 0.91 & 0.86 & 9 \\
8 & Danamon & 0.97 & 1.00 & 1.00 & 1.00 & 0.99 & 5 \\
9 & Mega & 0.44 & 0.47 & 0.62 & 0.71 & 0.56 & 12 \\
10 & Permata & 1.00 & 0.68 & 0.71 & 0.73 & 0.78 & 11 \\
11 & BNIS-BSM & 0.85 & 0.81 & 0.80 & 0.80 & 0.81 & 10 \\
12 & BRIS & 1.00 & 1.00 & 1.00 & 1.00 & 1.00 & 2 \\
\hline
\end{tabular}

Source: DEA Output (Data Processed)

From the several options above, regulators and Islamic banking need to consider the advantages and disadvantages of the merger, which Islamic banks look strong enough in terms of efficiency and ones that is relatively weak. From the result above, it is important to know so that in the future, the Islamic bank merger process will have a positive impact on increasing assets and the development of the Islamic banking industry in general in Indonesia.Based on Miftah and Wibowo (2017), some alternatives that are feasible considering the internal aspect such as tendency shareholder and condition sharia bank to be merged related to internal interest in the merger action and external aspect namely scale of assets from merger banks and probability success from merger process. In general valuation, sharia banks, both individual and consolidation (projection after-merger) are not optimal with price-to-book value (PBV) valuation in the range of 0.86-1.21 times(Miftah \& Wibowo, 2017).

In the future, this measurement also needs to be seen in terms of the level of productivity achieved by each state-owned Sharia bank.So that the results can reflect the real position from the perspective of bank efficiency and productivity, especially if it is associated with competition between Islamic banks and the conventional banking industry, which has existed for a long time.As we know, the performance comparison between Islamic banks and conventional banks is always interesting to see, especially in relation to the level of resilience of the Islamic banking industry in the banking and monetary sector in general. In addition, it is interesting to research, especially in the current era where MEA is in sight. Unlike abroad, there are too many banksin Indonesia, so they tend to be less efficient. 


\section{CONCLUSION}

Based on the efficiency analysis of the three state-owned Islamic commercial banks that will be merged, namely Bank BRI Syariah, BNI Syariah, and Bank Syariah Mandiri with ten conventional banks for the period 2016-2019, the Islamic Bank still have a low efficient level of performance compare to conventional. Meanwhile, from the five models to obtain various considerations on the planned merger of the state-owned Islamic bank, it can be seen that BNI Syariah has the highest and perfect efficiency score than BRISyariah and Bank Syariah Mandiri.

On the other hand, if the three Islamic banks are combined into a state-owned Islamic bank, it will have an efficiency score of 0.86 . Therefore, state-owned sharia banks must improve their performance efficiency in order to be able to compete in the national banking industry. Moreover, if only two Islamic banks are merged, namely BNISyariah and BRISyariah, it will produce perfect efficiency values. Meanwhile, if the merger of BankSyariahMandiri and BRISyariah will result in an efficiency score of 0.70 , and if BNISyariah and Bank Syariah Mandiri are combined, it will produce an efficiency score of 0.81 . Of the three merger results, only the two banks, the most likely merger to achieve a perfect efficiency score was the merger between BNI Syariah and BRI Syariah.The results of the analysis of this study are important for Bank Indonesia (BI) and the Financial Services Authority (OJK) as regulators to determine which conditions of Islamic banks are good for merging in terms of their historical performance efficiency levels. For each bank, this research can be used to see the performance of each bank during the research period, and for academics, this research can be an interesting issue to research and develop.

\section{ACKNOWLEDGMENT}

Sincere gratitude to the parties who help this study. Thank you to Allah SWT for His help. Also, thank you to our beloved parents, friends, and colleagues. We hope this study would be a help for the development of Islamic banking in Indonesia.

\section{REFERENCES}

Benarda, B., Sumarwan, U., \& Hosen, M. N. (2016). Tingkat Efisiensi Industri Asuransi Jiwa Syariah Menggunakan Pendekatan Two Stage Data Envelopment Analysis. Jurnal Aplikasi Bisnis Dan Manajemen (JABM), 2(1), 64. https://doi.org/10.17358/jabm.2.1.64

Berger, A. N., \& Humphrey, D. B. (1997). Efficiency of Financial Institutions: International Survey and Directions for Future Research. European Journal of Operational Research, 98(2), 175-212. https://doi.org/10.1016/S0377-2217(96)00342-6

Cambridge Institute of Islamic Finance. (2018). Global Islamic Finance Report 2018. Cooper, W. W., Seiford, L. M., \& Joe, Z. (2004). Handbook on Data Envelopment Analysis (W. W. Cooper, L. M. Seiford, \& J. Zhu (eds.); Vol. 71). Springer US. 
https://doi.org/10.1007/b105307

Cooper, W. W., Seiford, L. M., \& Tone, K. (2006). Introduction to Data Envelopment Analysis and Its Uses: With DEA-Solver Software and Refrences. Springer Science \& Business Media.

Farrell, M. J. (1957). The Measurement of Productivity Efficiency. Journal of the Royal Statistical Society: Series A (General), 120(3), 253-290. https://doi.org/10.2307/2343100

Hafez, H. M., \& Halim, M. (2019). The Efficiency of Islamic Banks versus Conventional Banks: An Empirical Study of An Emerging Economy. Banks and Bank Systems, 14(2), 50-62. https://doi.org/10.21511/bbs.14(2).2019.05

Hassan, M. K. (2006). Cost, Profit, and X-Efficiency of Islamic Banks in Pakistan, Iran, and Sudan. In T. Khan \& D. Muljawan (Eds.), Proceedings of The International Conference on Islamic Banking: Risk Management, Regulation, and Supervision (pp. 497-509). Islamic Research and Training Institute.

Havidz, S. A. H., \& Setiawan, C. (2015). A Comperative Study of Efficiency between Conventional and Islamic Banks in Indonesia. Asian Economic and Financial Review, 5(5), 790-804. https://doi.org/10.18488/journal.aefr/2015.5.5/102.5.790.804

Hidayah, N., \& Purnomo, D. (2016). Tingkat Efisiensi Perbankan Konvensional dan Perbankan Syariah di Indonesia. Journal of Islamic Economics and Finance, 2(2). https://doi.org/10.20885/jeki.vol2.iss2.art4

Insukindro, I., Nopirin, N., Makhfatih, A., \& Ciptono, S. M. (2000). Laporan Akhir Pengukuran Efisiensi Relatif Pelayanan Kantor Cabang Pegadaian Yogyakarta. Penelitian dan Pengembangan Manajemen (PPM)) Fakultas Ekonomi Universitas Gadjah Mada.

Irfan, M., Majeed, Y., \& Zaman, K. (2014). The Performance and Efficiency of Islamic Banking in South Asian Countries. Economia. Seria Management, 17(2), 223-237. http://www.management.ase.ro/reveconomia/2014-2/3.pdf

Jaouadi, S., \& Zorgui, I. (2014). Exploring Effectiveness and Efficiency of Banks in Switzerland. International Journal of Academic Research in Business and Social Sciences, 4(4), 313-325. https://doi.org/10.6007/IJARBSS/v4-i4/787

Kablan, S., \& Yousfi, O. (2013). What Drives Efficiency of Islamic Banks Among Regions? Journal of Applied Business Research, 29(5), 1411-1420. https://doi.org/10.19030/jabr.v29i5.8071

Karim, A. (2018). Ekonomi Mikro Islami (10th ed.). Rajawali Pers. http://www.rajagrafindo.co.id/produk/ekonomi-mikro-islami/

Khan, A., \& Noreen, U. (2014). Efficiency Measure of Insurance v/s Takaful Firms Using DEA Approach: A Case of Pakistan. Journal of Islamic Economic Studies, 22(1), 139-158. https://doi.org/10.12816/0004133

Miftah, K., \& Wibowo, H. (2017). Merger and Industrial Acceleration: Study at Indonesian Islamic Banking Industry. Signifikan: Jurnal IImu Ekonomi, 6(1), 29-48. https://doi.org/10.15408/sjie.v6i1.4728 
Miniaoui, H., \& Chaibi, A. (2014). Technical Efficiency of Takaful Industry: A Comparative Study of Malaysia and GCG Countries.

Mokhtar, H. S. A., Abdullah, N., \& Al-Habshi, S. M. (2006). Efficiency of Islamic Banking in Malaysia: A Stochastic Frontier Approach. Journal of Economic Cooperartion, 27(2), 37-70. https://sesric.org/files/article/22.pdf

Rahman, M. A. (2013). Comparative Study on The Efficiency of Bangladeshi Conventional and Islamic Life Insurance Indsutry: A Non-Parametric Approach. Asian Business Review, 3(2), 80-91. https://doi.org/10.18034/abr.v3i2.91

Rusydiana, A. S. (2018a). Efisiensi dan Stabilitas Bank Umum Syariah di Indonesia. Akuntanbilitas: Jurnal IImu Akuntansi, 11(2), 203-222.

https://doi.org/10.15408/akt.v11i2.7033

Rusydiana, A. S. (2018b). Malmquist Index to Measure The Efficiency and Productivity of Indonesia Islamic Banks. Jurnal Ekonomi Dan Pembangunan, 26(1), 47-58. https://doi.org/10.14203/JEP.26.1.2018.47-58

Rusydiana, A. S., \& Firmansyah, I. (2017). Efficiency Versus Maqashid Sharia Index: An Application on Indonesian Islamic Bank. Shirkah: Journal of Economics and Business, 2(2), 139-166. https://doi.org/10.22515/shirkah.v2i2.154

Rusydiana, A. S., Laila, N., \& Sudana, S. (2019). Efisiensi dan Produktivitas Industri Perbankan pada Sistem Moneter Ganda di Indonesia. Jurnal Siasat Bisnis, 23(1), 50-66. https://doi.org/10.20885/jsb.vol23.iss1.art5

Rusydiana, A. S., \& Marlina, L. (2019). Financial and Social Efficiency on Indonesian Islamic Banks: A Non-Parametic Approach. Journal of Islamic Monetary Economics and Finance, 5(3), 579-602. https://doi.org/10.21098/jimf.v5i3.1154

Rusydiana, A. S., \& Sanrego, Y. D. (2018). Measuring The Performance of Islamic Banking in Indonesia: An Application of Mashlahah-Efficiency Quadrant (MEQ). Journal of Islamic Monetary Economics and Finance, 3, 79-98. https://doi.org/10.21098/jimf.v3i0.909

Sabiti, M. B., Effendi, J., \& Novianti, T. (2017). Efisiensi Asuransi Syariah di Indonesia dengan pendekatan Data Envelopment Analysis. Al-Muzara'ah, 5(1), 69-87. https://doi.org/10.29244/jam.5.1.69-87

Shahreki, J., Dahmardeh, N., \& Ghasemi, M. A. (2012). Efficiency Evaluation Bank Sepah Branches in Sistan and Baluchestan Province (S\&B, Iran), Using Data Envelopment Analysis. Interdisciplinary Journal of Contemporary Research in Business, 4(2). https://journal-archieves19.webs.com/june12.pdf

Shawtari, F. A. M., Kareem, M. A. A., \& Razak, S. H. A. (2014). Efficiency and Stability Assessment of The Yemeni Banking Sector Using Data Envelopment Window Analysis (DEWA). In A. Emrouznejad, R. Banker, S. M. Doraisamy, \& B. Arabi (Eds.), Procedings of The 12th International Conference of DEA (pp. 144-153).

Suryani, S. (2012). Sistem Perbankan Islam di Indonesia: Sejarah dan Prospek Pengembangan. Muqtasid: Journal of Islamic Economics and Banking, 3(1), 111131. https://doi.org/10.18326/muqtasid.v3i1.111-131

Tuffahati, H., Mardian, S., \& Suprapto, E. (2016). Pengukuran Efisiensi Asuransi Syariah Dengan Data Envelopment Analysis (DEA). Jurnal Akuntasi Dan Keuangan Islam, 4(1), 1-24. https://doi.org/10.35836/jakis.v4i1.27 